\title{
Is it just too hard? Gender time symmetry in market and nonmarket work and subjective time pressure in Australia, Finland and Korea
}

\author{
Lyn Craig*, Judith E. Brown, Lyndall Strazdins and Jiweon Jun
}

*lyn.craig@unimelb.edu.au ORCID: 0000-0001-9723-7255

This is a post-peer-reviewed, pre-copyedited version of a chapter published as: Craig L., Brown J.E., Strazdins L., Jun J. (2017) Is It Just Too Hard? Gender Time Symmetry in Market and Nonmarket Work and Subjective Time Pressure in Australia, Finland, and Korea. In: Connelly R., Kongar E. (eds) Gender and Time Use in a Global Context. Palgrave Macmillan, New York.

doi.org/10.1057/978-1-137-56837-3_18

\section{Introduction}

Gender equality in time spent in market work and in the unpaid domestic work of housework and family care is widely seen as desirable, potentially enhancing women's financial security and allowing men to participate more fully in family life (Plibersek 2008, Nedelsky 2016, Connell 2003). But is there a stress cost to couples sharing both forms of labor equally? As work and family demands have escalated over recent decades, time scarcity has become a pervasive feature of contemporary life (Jacobs and Gerson 2004). Feeling constantly rushed and harried - experiencing subjective time stress - can adversely affect wellbeing (Strazdins et al. 2011). Does gendered time equality, with men and women both juggling work and family demands, engender higher subjective time stress than gender specialization? The answer may vary crossnationally, because some countries provide more policy support for work-family reconciliation, and have lower average work-weeks, making it easier for couples to manage more gender-equal shares of market and non-market work (Gornick and Meyers 2003).

\section{Background}

When second-wave feminism began gaining ground in the mid-20 ${ }^{\text {th }}$ century, proponents expected that as women entered the paid workforce, there would be a complementary increase in men's domestic activities, and household labor would also become more equal (Young and Wilmott 1973, Bergmann 1986). "Generally, feminists look to a future in which women and men are equal in opportunity, in respect and in the burdens they carry" (Bergmann 1986). The expectation was that when women earned more, they would have more power in the family, so equality between husband and wife in domestic labor should be easier to achieve (Hartmann 1981, Bergmann 1986). The assumption arose partly from simple logic. One consequence of women's increasing time in market employment should be men's increasing domesticity (Oakley 1985). It was assumed that the family would act as a self-balancing system in which, if one member withdrew from certain types of labor, another would take over that labor. This was called the 'adaptive partnership model' (Meissner et al. 1975) leading to 'the symmetrical family' (Young and Wilmott 1973) with gender equality in both market and nonmarket work.

The symmetrical family is still a desired social goal. Many see gender equality in paid and unpaid work as prerequisite to women's financial security and men's involvement in family life (Plibersek 2008, Nedelsky 2016, Baxter, Hewitt, and Haynes 2008, Connell 2003). A gender imbalance whereby women interrupt their careers or work part time to care for children or other family members, while most men are employed full time over the working lifetime, has potential negative effects on the welfare of both sexes (Anxo et al. 2007, HREOC 2007). Women are disadvantaged financially through gender pay gaps and lower lifetime earnings, and the pressure to be the main family provider, particularly if long hours are required, can be a source of 
stress and damage to men (Hill et al. 2004). Men and women doing similar amounts of both market and nonmarket work seems to offer a solution to these problems (Connell 2003, Nedelsky 2016).

Notwithstanding its appeal, the symmetrical family has not yet become the norm. Reasons are various, but may include that market work hours have gone up, and that rather than engendering a trade-off between men and women, female employment has meant households do more work overall. In US families, for example, four decades ago, most fathers were the sole breadwinners, and on average, household time allocation to market work was just over 44 hours a week. By 2000, most US couples with children were dual-earners, devoting more than 80 hours a week to market employment (Strazdins et al. 2011, Jacobs and Gerson 2004). Over the same period, women's time in domestic work trended downward, but at a rate far short of the rise in their paid work time (Bianchi et al. 2000). There is some evidence that men's average paid work time trended down, but that, for those who are employed full time, work hours are higher (Pocock 2003, Robinson and Godbey 1997, Gershuny 2011, Kan, Sullivan, and Gershuny 2011). In Western countries men's housework time increased slightly, and mothers' and fathers' child caregiving time has actually gone up (Sayer 2016, Craig, Mullan, and Blaxland 2010, Sullivan 2011). Together these trends imply that in couple households, total workloads - the time committed to employment and to the unpaid work of domestic labor and care by both partners together - have increased (Craig and Mullan 2009).

This may be a reason why symmetrical families remain relatively rare. If greater gendered time equality is accompanied by higher total household workloads, as implied by the trends noted above, it may not enhance well-being, and symmetry may just be too demanding and stressful for many couples to achieve. Escalating time pressures upon modern families are widely noted in both academic and popular discussions (see for example Schulte 2014, Presser 2003, Mattingly and Sayer 2006, Bianchi and Milkie 2010, Edwards and Wajcman 2005), with employed parents of young children, especially, reporting extremely high levels of subjective time stress (Craig and Mullan 2009). If both partners are overworked, the stresses could be magnified. Couples could be giving up joint family or couple leisure time or eating meals together, at cost to health, family well being and relationship quality (Strazdins et al. 2011). Role convergence may bring more gender symmetry in the division of labor at the cost of higher time stress for both partners, making it too hard to manage. However, to date no research has explicitly examined whether gender-equal shares of market and nonmarket work are associated with higher subjective time pressure.

Indeed surprisingly little about is known about the incidence and profile of gender-equal sharers, and what spending equal time in market and nonmarket work might mean for men and for women. Missing from the literature is a picture of how the time allocation of men and women in gender-symmetrical couple households differs from that of men and women in gender-asymmetrical couple households. Thus, as a first step in this chapter, we compare total work hours, and its composition (market or nonmarket) by gender, in couples who have approximately equal shares of both types of work, with couples who do not. Knowledge of these patterns is prerequisite to understanding relationships between gendered time in/equality and feeling rushed and harried. This is because the literature suggests that market and nonmarket work relate to subjective time pressure in contrasting ways. That is, while higher overall workloads are likely to engender feelings of being rushed, how that work is proportionately comprised of market or nonmarket labor is likely to also matter.

It is certainly the case that market work matters to time stress. It is well-established that longer employment hours cause people to feel more rushed, harried and short of time (Beaujot and Andersen 2007, Mattingly and Sayer 2006, Craig and Baxter 2016, Hamermesh and Lee 2007, Kleiner 2014). Recent evidence also points to cross-spousal effects, finding long male paid work hours to be associated with higher subjective time stress not only for the men who work them, but also for their spouse (Craig and Brown 2016). However, it is not so clear whether time spent in nonmarket work is related to subjective time pressure. Investigation has yielded mixed results. Australian research found more nonmarket work was negatively associated with time stress for both men and women (Craig and Brown 2016), US research found no association for either gender (Mattingly and Sayer 2006), and research in Canada and Denmark has found weak positive associations, but only for women (Beaujot and Andersen 2007, Deding and Lausten 2011). 
The findings are inconclusive, but overall suggest a weaker link between nonmarket work and time stress than between market work and time stress.

The implication is that workloads that involve a higher proportion of unpaid work may be less stressful than those that involve a higher proportion of paid work, which raises the further possibility that relationships between gender symmetry and time stress differ by gender. If gender time symmetry involves more market work for women and less for men, and more nonmarket work for men and less for women, time stress in equal-sharing households could be higher for women and lower for men. It is, of course, also possible that more-equal shares of market and nonmarket work could engender similar levels of time stress for both men and women. Juggling paid and unpaid work may entail conflicting demands and responsibilities not present when there is greater specialization in one type of work (MacDonald, Phipps, and Lethbridge 2005), causing additional subjective time pressure for both men and women in egalitarian households.

Investigating relationships between subjective time pressure and gender a/symmetry in market and nonmarket work is a new contribution to the literature. To date, studies examining gender patterns in subjective time stress focus on how it relates to men and women's absolute time in market and/or nonmarket work, not on how couples' total workloads are shared proportionately (Mattingly and Sayer 2006, Hamermesh and Lee 2007, see for example Craig and Baxter 2016). Here we take a different approach, and directly consider relationships between gendered time equity, defined as gender symmetry in both market and nonmarket work, and subjective time pressure.

Associations between time stress and gender symmetry may differ across countries, so our enquiry will be placed within a cross-national perspective. Both total time allocation to market and nonmarket work and the way they are divided within households are a result not only of individual and family choices, but also of the normative, cultural, and policy environment (Gornick and Meyers 2003). Countries vary in work-family policies including support for care (paid parental leave, state services for child care, aged care services), and in regulation of paid work time (annual hours, daily work limits, vacation time, flexibility, higher hourly rates for nonstandard work schedules) (Lewis 2009, Gornick and Meyers 2003, Crompton 2006). Such policies shape gender norms, reinforce workplace cultures, and importantly, also influence the gender division of labor (Crompton 2006, Hook 2006, 2010, Sayer and Gornick 2012, Gershuny and Sullivan 2003, Craig and Mullan 2010). For example, measures such as regulated short working hours, affordable public childcare or national mandated paid parental leave for mothers and fathers facilitate gender symmetry in market and nonmarket work, whereas their absence promotes gender specialization (Gornick and Meyers 2003, Lewis 2009).

We speculate that having extensive policy supports for work-family reconciliation will also mean gender symmetry is experienced differently than in policy environments that leave such arrangements to families and individuals to organize privately. Specifically, we expect it to be more stressful if fewer supports are provided. In a further new contribution to the literature, this paper will investigate this possibility by exploring relationships between gendered time in/equity and subjective time stress in Australia, Finland and Korea, three countries with differing institutional frameworks in relation to work time regimes, work-family reconciliation, and gender equality.

\section{Country context}

Comparative analyses draw on a body of literature that categorized countries into typologies according to how they draw on the key pillars of welfare: states, markets and families (Esping-Andersen 2009, O'Connor, Orloff, and Shaver 1999). Comparative time use analyses have shown important differences between social democratic (exemplified by Scandinavia), familialist (exemplified by Southern Europe) and liberal/market oriented regimes (exemplified by the English speaking countries) in employment hours, employment rates, non-standard work, women's workforce participation and men's nonmarket work time (Crompton 2006, Hook 2006, 2010, Sayer and Gornick 2012). Families in market-oriented regimes such as Australia have been found to have higher combined total workloads, and wider gender gaps in paid and unpaid work than 
Northern European countries such as Finland (Craig and Mullan 2010, Gornick and Meyers 2003, Gershuny and Sullivan 2003). Previous cross-national research into family time allocation has rarely included Asian countries. North Asian countries have a reputation for very long full time working hours, but also a strong tradition of relying on family to provide child and elder-care (Kwon 2005, Lee 2005, Ochiai 2009). They exhibit liberal/market-oriented features in paid work, and familialist features in unpaid work, so some argue that within welfare regime typologies they could be described as liberal-familialist (Kwon 2005, Lee 2005, Ochiai 2009).

This paper offers new insights into the interplay between family life and social context by examining whether and how subjective time pressure is related to gender shares of market and nonmarket work in Australia (market-oriented), Korea (liberal-familialist) and Finland (social democratic). Table 1 summarizes some of the

\section{Table 1: Features of institutional context in Australia, Italy, Korea and Finland}

\begin{tabular}{|c|c|c|c|}
\hline & Australia & Korea & Finland \\
\hline Tertiary education (aged 25-64) $2009^{1}(\%)$ & 37 & 39 & 37 \\
\hline Male employment rates aged 15-64 $2009(\%)^{2}$ & 77.8 & 73.6 & 68.9 \\
\hline Female employment rates aged 15-64 2009 (\%) ${ }^{2}$ & 66.3 & 52.2 & 67.9 \\
\hline Female part-time employment $2013(\%)^{2}$ & 38.1 & 16.2 & 16.7 \\
\hline Percentage of men who usually work $40+$ hours $2011^{2}$ & 62 & 85 & 53.9 \\
\hline Public expenditure on formal childcare \% GDP $2009^{3}$ & 0.6 & 0.7 & 1.1 \\
\hline \multicolumn{4}{|l|}{ Enrollment rates for formal childcare/early education $2008(\%)^{4}$} \\
\hline Children 0 - 2 years & 29 & 19 & 28 \\
\hline Children 3 - 5 years & 55 & 83 & 73 \\
\hline Total fertility rates $2009(\%)^{5}$ & 2.0 & 1.2 & 1.9 \\
\hline Gender wage gap in median earnings of full-time employees $2009^{6}$ & 16.4 & 38.6 & 19.7 \\
\hline Global Gender Gap Index 20097 & 0.73 & 0.61 & 0.83 \\
\hline
\end{tabular}

Notes: Time periods closest available match to the available Time Use Data

1. Education at a Glance 2011 OECD indicators http://www.oecd.org/edu/Chapter1-TablesandCharts-IEAG2015web.xlsx

2. OECD Family database. (http://www.oecd.org/els/soc/LMF_1_6_Gender_differences_in_employment_outcomes.xlsx) For Korea KOSIS (Korean statistical database) 2009 all women aged 15 and above

3. OECD Family database(http://www.oecd.org/els/soc/PF3_1_Public_spending_on_childcare_and_early_education_Dec2014.xls)

4. OECD Family database (http://www.oecd.org/els/soc/PF3_2_Enrolment_childcare_preschool.xlsx)., Korea aged 3-5 2010.

5. OECD Family database(http://www.oecd.org/els/soc/SF_2_1_Fertility_rates.xlsx)

6. OECD Family database(http://www.oecd.org/els/family/LMF_1_5_Gender_pay_gaps_for_full_time_workers.xlsx) A 2010

7. The Global Gender Gap Report. Geneva: World Economic Forumhttp://www3.weforum.org/docs/WEF GenderGap Report 2009.pdf.

Tertiary education is broadly similar across the countries (Table 1). However, there are differences by gender. In Australia and Finland a higher proportion of women than men have tertiary qualifications (40 percent versus 34 percent for Australia and 43 percent versus 31 percent for Finland). In Korea a higher proportion of men (44 percent) than women (34 percent) have a tertiary qualification.

Male employment rates are highest in Australia and lowest in Finland (see Table 1). Female employment rates are lowest in Korea (52 percent). Overall female participation rates in Australia and Finland are similar at about 68 percent, but 38 percent of Australian women work part time, compared to about 16 percent in Korea and Finland. Nearly 85 percent of men in Korea work over 40 hours a week, substantially higher than men in Australia (62 percent) and Finland (53 percent). The figures imply that average male market work hours are lowest in Finland. They also show that gender gaps in workforce participation are substantial in all three countries, but they are least in Finland and most in Korea.

Affordable, accessible childcare is essential to underpin female workforce participation (Gornick and 
Meyers 2003). Finland spends more than 1 percent of their Gross Domestic Product (GDP) on formal childcare/early education, whereas Australia and Korea spend 0.6 and 0.7 percent respectively. Compared to Australia and Finland, attendance rates for Korea are lowest for children aged 0-2 years, but highest for 3-5 year olds, signaling that Korean children begin attending formal early education at age three. Enrollment rates are consistently high in Finland for both age groups: 28 percent for 0-2 years and 73 percent for 3-5 year olds. Attendance for 3-5 year olds is, at 55 percent, lowest in Australia.

The countries differ in their fertility rates, with Australia (2 percent) and Finland (1.9 percent) at near replacement, and Korea very low at a below-replacement 1.2 percent. Low fertility rates are endemic throughout Asia, and have been attributed to gender inequities in market and nonmarket work, on the basis that women will forego motherhood if it is too costly in high time allocation to domestic work and in foregone earnings (de Laat and Sevilla Sanz 2004, McDonald 2006).

There is very large disparity in the gender wage gap for full time workers across the countries, with Korea extremely high at 39 percentage points. The other countries are also substantial, with Finland (19.2) wider than Australia (16.4). The gap in Finland may reflect occupational segregation, which is quite marked in Scandinavian countries, where women are much more likely than men to work in care and social services (Orloff 2009). Korea also scores lowest on the Global Gender Gap Index, which covers a range from 0 meaning complete inequality to 1 meaning complete equality on a range of criteria including political representation, health outcomes and financial wellbeing (see Hausmann, Tyson, and Zahidi 2009 for details). Korea scores 0.61, compared to 0.83 for Finland, and 0.73 for Australia.

Taken together, these institutional features and social indicators suggest that of the three countries, Finland has the most extensive work-family supports and is the most progressive in promoting gender equality, Korea is the least progressive, and Australia falls in between. Also, male paid work hours are particularly long in Korea, intermediate in Australia, and least in Finland. We noted above that the literature suggests longer working hours engender more time stress and that we expect gender symmetry would not only be more common, but also, less stressful in countries that have public policy supports for work-family reconciliation. Given the country profiles in relation to these two factors, we expect that associations between time stress and gender symmetry will be particularly strong for women in Korea.

\section{Research focus}

The central aim of this paper is to investigate whether gender symmetry in couples' market and nonmarket work relates to their subjective time pressure, and whether cross-national differences in workplace and social policy settings may be relevant to these relationships. Because this issue is new to the literature, we first conduct descriptive analyses to examine total household workloads (couples combined paid and unpaid work) and identify how prevalent gender-equal divisions of labor are in couple households in Australia, Korea, and Finland. We compare, by country, gender differences in household work composition by whether or not couples have gender-equal shares of market and nonmarket work. We show how average time in each type of work (market or nonmarket) varies from the norm for each gender, in each country, in households that achieve symmetry. Then, using logistic regression modelling, we examine in each country associations between time a/symmetry and subjective time pressure and whether these associations vary by gender.

\section{Data and Method}

\section{Data}

We used Time Use Surveys (TUS) of Australia (2006), Korea (2009) and Finland (2009) conducted by the national statistical agency of each country. Each contains representative samples of the respective country populations. All the surveys collected information through a self-completed time diary covering weekdays and weekend days, although ratios of day type differ. The Australian and Korean TUS collected data over two consecutive days while the Finnish TUS collected data for one weekday and one weekend day. In all 
three countries multiple members of the sampled households participated so it was possible to derive individual and household level data and analyze the time of men and women living together. We drew a sample of 20-64 year old men and women in couple-headed households with and without children, consisting of 1458 households and 2873 diaries from the Australian TUS, 4374 households and 8748 diaries from the Korean TUS, and 781 households and 1543 diaries from the Finnish TUS.

\section{Dependent variables}

We calculated daily time spent by men and women, and by couples combined, in market and nonmarket work comprised of employment, child caregiving, housework and related travel. To maximize cross-national comparability (Mullan and Craig 2009), we analyzed only primary activity. For detailed codes see Appendix 1.

Our key outcome variable is subjective time stress, which in each country was measured through a survey question. In the Australian TUS the question read "how often do you feel rushed or pressed for time?" The response categories were "always" "often”, "sometimes”, "rarely” and "never”. The Korean TUS asked "in daily life do you feel busy or pressed for time?” Response categories were "yes, always”, "yes, sometimes”, "not really" and "never”. The Finnish TUS asked "how often do you feel rushed?" Response categories were "all the time", "from time to time" and "hardly ever". We dichotomize responses into a binary outcome variable that contrasts those who "always/all the time" or "often" feel time stressed with those who "sometimes/from time to time", "rarely/not really" or "never/hardly ever" do so. That the Australian TUS had five response categories while Korean and Finish TUS had fewer is an important point of difference, and means we can directly compare time stress only within, not between, countries. We use the terms "time stress”, "subjective time pressure” and "feeling rushed or pressed for time” interchangeably.

\section{Analysis plan and independent variables}

We began our analyses with a descriptive overview of key time use variables. To measure household gender shares, we first calculated men and women's paid work hours as a proportion of the total market work performed by the couple combined. Likewise we calculated their unpaid work as the proportion of the total nonmarket work performed by the couple combined. We classified each diary day as being symmetrical or asymmetrical. Symmetry was defined as both the market work share and the nonmarket work share being more than or equal to 0.4 and less than or equal to 0.6 . That is, as 50:50 plus or minus 10 percent on both forms of work. Preliminary investigation showed gender symmetry was more likely to occur on weekends, because they are days on which less work is performed overall. Therefore our descriptive overview of time spent in market and nonmarket work and gender a/symmetry by country used simple linear models which controlled for day of the week.

We used logistic regression analyses to investigate how gender a/symmetry related to men and women's subjective time stress in each of the three countries. We stratified our analyses by country because of language and definition differences in the key time pressure question. Our key independent variables were gender, gender a/symmetry and interactions between them.

The models controlled for factors that may have an independent relationship with time stress. We captured parenthood (Craig and Mullan 2009) by a series of dummy variables: no children (omitted), age of the youngest child is 0-4 years, 5-9 years, or 10-14 years. We also tested interactions between age of children and gender. We entered respondent's age (in years) because patterns in employment and nonmarket work vary over the life course (Baxter 2002, Hendricks and Cutler 2003). For Korea and Finland age was provided as a continuous variable. In the Australian data, age was provided in 5-year bands and we take the midpoint of each to generate a continuous variable. We included education as a dummy defined as both partners have a college degree yes or no because human capital has been found to be related to both time use and subjective time pressure (Gershuny 2005, Hamermesh and Lee 2007). We controlled for the presence of three or more adults in the household to account for any additional workload or benefit that may be gained 
from having other adults in the house. We held constant the couple's total combined daily market and nonmarket work, so relationships between time stress and gender shares were assessed independently of overall amount of work.

\section{Results}

Table 2 describes the sample and delineates country and gender differences in the independent variables. ${ }^{1}$ It reveals some demographic contrasts in our sample. A lower percentage of households had no young children in Korea (43 percent) than in Australia (45 percent) and Finland (49 percent). This is inconsistent with the low fertility rate in Korea shown in Table 1, but likely results from our couple-only sample. Having adults other than the conjugal couple in the household is more common in Korea (41 percent) than Australia (31 percent) and Finland (30 percent). As expected, gender symmetry was most prevalent in Finland, where couples equally shared market and nonmarket work on 25 percent of diary days. Korean households were the most imbalanced with less than 6 percent of diary days classified as symmetrical, and Australia occupied the middle ground with 18 percent.

\section{Table 2: Descriptive statistics for Italy, Australia, Korea and Finland for household and individual variables}

\begin{tabular}{|c|c|c|c|c|c|c|}
\hline \multirow{2}{*}{ Household variables } & \multicolumn{2}{|c|}{ Australia } & \multicolumn{2}{|c|}{ Korea } & \multicolumn{2}{|c|}{ Finland } \\
\hline & & & \multirow{2}{*}{\multicolumn{2}{|c|}{4374}} & \multirow{2}{*}{\multicolumn{2}{|c|}{781}} \\
\hline \multirow[t]{2}{*}{ Number of households } & \multicolumn{2}{|c|}{1458} & & & & \\
\hline & \multicolumn{2}{|c|}{$\%$} & \multicolumn{2}{|c|}{$\%$} & \multicolumn{2}{|c|}{$\%$} \\
\hline \multicolumn{7}{|l|}{ Age of the youngest child } \\
\hline No children & \multicolumn{2}{|c|}{45.3} & \multicolumn{2}{|r|}{42.9} & \multicolumn{2}{|c|}{49.4} \\
\hline Aged 0-4 & \multicolumn{2}{|c|}{26.1} & \multicolumn{2}{|r|}{19.9} & \multicolumn{2}{|c|}{22.3} \\
\hline Aged 5-9 & \multicolumn{2}{|c|}{14.9} & \multicolumn{2}{|r|}{16.6} & \multicolumn{2}{|c|}{13.8} \\
\hline Aged 10-14 & \multicolumn{2}{|c|}{13.7} & \multicolumn{2}{|r|}{20.7} & \multicolumn{2}{|c|}{14.5} \\
\hline Both partners have college degree & \multicolumn{2}{|c|}{21.9} & \multicolumn{2}{|r|}{15.4} & \multicolumn{2}{|c|}{16.1} \\
\hline $3+$ adults in the house & \multicolumn{2}{|c|}{30.8} & \multicolumn{2}{|r|}{40.9} & \multicolumn{2}{|c|}{30.1} \\
\hline 2+ children & \multicolumn{2}{|c|}{34.6} & \multicolumn{2}{|r|}{31.7} & \multicolumn{2}{|c|}{29.1} \\
\hline Gender symmetry in market and nonmarket & \multicolumn{2}{|c|}{18.3} & \multicolumn{2}{|r|}{5.5} & & 25.2 \\
\hline Person variables & & & & & & \\
\hline & Men & Women & Men & Women & Men & Women \\
\hline High subjective time stress & 61.7 & 65.0 & 35.2 & 30.5 & 22.0 & 20.0 \\
\hline Employment status & & & & & & \\
\hline Full-time & 84.4 & 35.5 & 89.3 & 44.1 & 82.1 & 71.7 \\
\hline Part-time & 7.3 & 40.1 & 5.0 & 11.6 & 3.5 & 12.5 \\
\hline Not in labor force & 8.4 & 24.4 & 5.7 & 44.3 & 14.4 & 15.7 \\
\hline Age (mean (SD)) & $\begin{array}{l}42.2 \\
(9.4)\end{array}$ & $\begin{array}{l}39.6 \\
(8.7)\end{array}$ & $\begin{array}{l}43.7 \\
(8.2)\end{array}$ & $\begin{array}{l}40.7 \\
(7.6)\end{array}$ & $\begin{array}{l}42.4 \\
(9.9)\end{array}$ & $\begin{array}{l}39.9 \\
(9.1)\end{array}$ \\
\hline
\end{tabular}

Table 2 also suggests that average reported time stress is much higher in Australia than the other countries. It is lowest in Finland. This could be a result of the coding differences discussed above and for this reason we place more reliance on within-country than between-country differences. Patterns in education and employment were consistent with those in Table 1 above.

\section{Time use by gender and country}

To show how total household workload is constructed by gender and country, the average weekly market and nonmarket work of men and of women is presented in Table 3. Men in Korea average more weekly market work (48.4 hours) than men in Australia (42.4 hours) or Finland (28.8 hours). ${ }^{2}$. Australian women's 
average weekly paid work (19.8 hours) was statistically lower than Korea (22.1 hours) and Finland (24.1 hours), but did not differ statistically between the latter two countries. Korean men spend much less time per week in nonmarket work (6.5 hours), than Australian (20 hours) or Finnish men (19.3 hours). The difference between Korea and each of the other countries is significant, but there was no significant difference between Australia and Finland. There were also significant differences in women's weekly nonmarket work among Australia (41.6 hours), Korea (35.6 hours) and Finland (29.0 hours).

Table 3: Mean hours per week spent in market and nonmarket work by men and women in Australia, Korea and Finland

\begin{tabular}{|c|c|c|c|c|c|c|}
\hline Diary variables & \multicolumn{2}{|c|}{ Australia } & \multicolumn{2}{|c|}{ Korea } & \multicolumn{2}{|c|}{ Finland } \\
\hline \multirow[t]{2}{*}{ Number of diaries } & \multicolumn{2}{|c|}{2873} & \multicolumn{2}{|c|}{8748} & \multicolumn{2}{|c|}{1543} \\
\hline & \multicolumn{2}{|c|}{ Mean (SD) } & \multicolumn{2}{|c|}{ Mean (SD) } & \multicolumn{2}{|c|}{ Mean (SD) } \\
\hline \multirow[t]{2}{*}{ Total household work } & \multicolumn{2}{|c|}{$123.8(43.6)$} & \multicolumn{2}{|c|}{$112.9(41.5)^{\mathrm{a}}$} & \multicolumn{2}{|c|}{$101.5(48.5)^{\mathrm{bc}}$} \\
\hline & Men & Women & Men & Women & Men & Women \\
\hline \multirow[t]{2}{*}{ Market work } & 42.2 & 19.8 & $48.4^{\mathrm{a}}$ & $22.1^{\mathrm{a}}$ & $28.8^{\mathrm{bc}}$ & $24.1^{\mathrm{c}}$ \\
\hline & (34.4) & $(28.1)$ & (31.1) & $(28.7)$ & (33.3) & (29.8) \\
\hline \multirow[t]{2}{*}{ Nonmarket work } & 20.0 & 41.6 & $6.4^{\mathrm{a}}$ & $35.6^{a}$ & $19.3^{b}$ & $29.0^{\mathrm{b}}$ \\
\hline & (19.1) & $(24.7)$ & $(10.4)$ & $(20.8)$ & $(16.9)$ & $(20.2)$ \\
\hline
\end{tabular}

Notes:

a Significant difference between Australia and Korea $(\mathrm{p}<0.01)$

b. Significant difference between Korea and Finland $(\mathrm{p}<0.01)$

c. Significant difference between Australia and Finland $(\mathrm{p}<0.01)$

Time metric modelled is hours per week. This was done to maintain consistency across all descriptive statistics and because the day type is not of important in and of itself. Using fitted values from the simple linear regression, synthetic weekly averages were calculated by summing the weekday estimate multiplied by five with the weekend day estimate multiplied by two and then divided by seven (as the metric used was hours per week).

Total weekly workloads were significantly lower in Korea (112.9 hours) and Finland (101.5 hours) than in Australia (123.8 hours). They were significantly lower in Finland than in Korea. Korean men's long market work hours were offset by their short nonmarket work hours. Australian households had the highest weekly workloads of the three countries due to men's fairly high paid work and nonmarket work combined with comparatively high nonmarket work for women. Low weekly total workloads in Finland were driven by the short male employment hours, and moderate female nonmarket work hours noted above.

Figure 1 illustrates what these patterns mean for the gender division of labor within each country. The extent that the bar is above the zero line signifies that men do more than women, and the extent to which the bar is below the zero line signifies that men do less than women. Gender gaps in market and nonmarket work were statistically significant in all the countries, but varied in magnitude. For Korea the gender difference was comprised of 26.3 hours market work (48.4-22.1) and 29.1 hours nonmarket work (35.6-6.5). This is larger than in Australia, where the gap is 22.4 hours per week (42.4-19.8) market work, and 21.6 hours per week (41.6-20.0) nonmarket work. It is much larger than in Finland where the gender difference is 4.7 hours per week (28.8-24.1) market work and 9.7 hours per week (29.0-19.3) nonmarket work. Thus, overall gaps between men and women were largest for Korea and smallest for Finland, consistent with the finding above that gender symmetry was most prevalent in Finland and least prevalent in Korea, with Australia occupying the middle ground. 
Figure 1: Differences in mean market and nonmarket work by men compared to women in Australia, Korea, and Finland

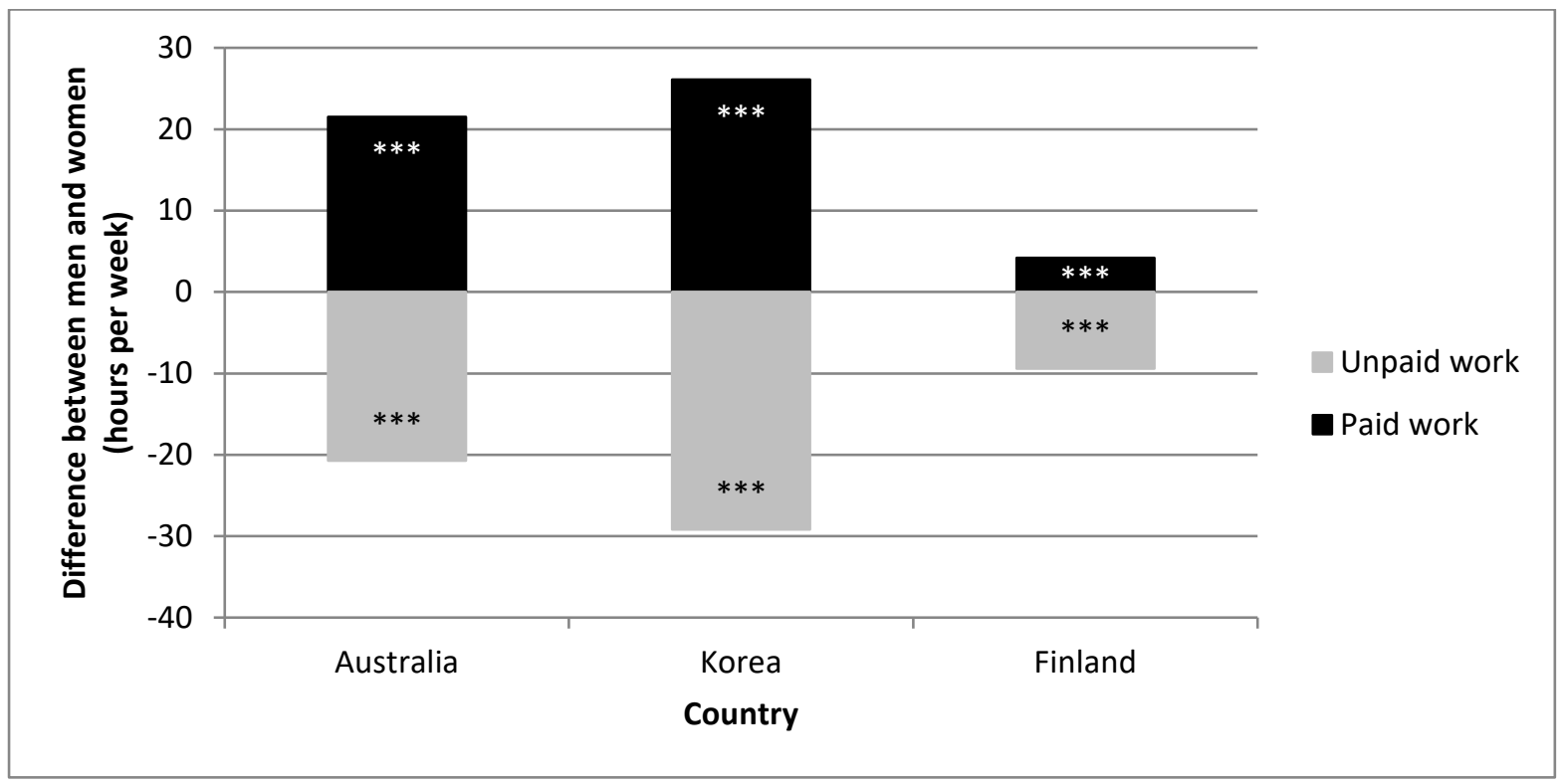

Note: the extent that the bar is above the zero line signifies that men do more than women, and the extent to which the bar is below the zero line signifies that men do less than women.

$* * * \mathrm{p}<0.001$ for differences for men compared to women

Time use by gender and country and a/symmetry

To consider differences in combined household workload, and for men and women separately, by household a/symmetry, we ran simple linear models controlling for day of the week. Results are presented in Table A2. Within all three countries there were no significant differences in total workloads by gender a/symmetry. Thus, the cross-country differences in total workload noted above, with Australia the longest, Finland the shortest and Korea in the middle, pertained in both symmetrical and non-symmetrical households. However, with regard to how total work was proportionately comprised of market and nonmarket work in each type of household, there were substantial country differences.

In Australia symmetrical households spent 14 fewer hours per week in market work and 11 hours per week more hours in nonmarket work than asymmetrical households. These differences are statistically significant. Similarly, in Finland, couples' combined weekly market work was significantly lower (14 hours) and their nonmarket work significantly higher (13 hours) in symmetrical, rather than non-symmetrical, households. That is, gender symmetry entailed more nonmarket and less market work at a household level in both Australia and Finland. In Korea, this was not the case. There, combined market work was statistically the same in both household types, whereas combined nonmarket work was higher (5 hours) in gender symmetrical households. ${ }^{3}$

There were also country differences in whether the time contrasts between symmetrical and nonsymmetrical households were driven by men or by women. These differences are illustrated in Figure 2 . The extent that the bar is above the zero line signifies that more work was done in symmetrical than nonsymmetrical households, and the extent to which the bar is below the zero line signifies that less work was done in symmetrical than non-symmetrical households. 
Figure 2: Differences in average market and nonmarket work by symmetrical compared to nonsymmetrical households for men and women in Australia, Korea and Finland

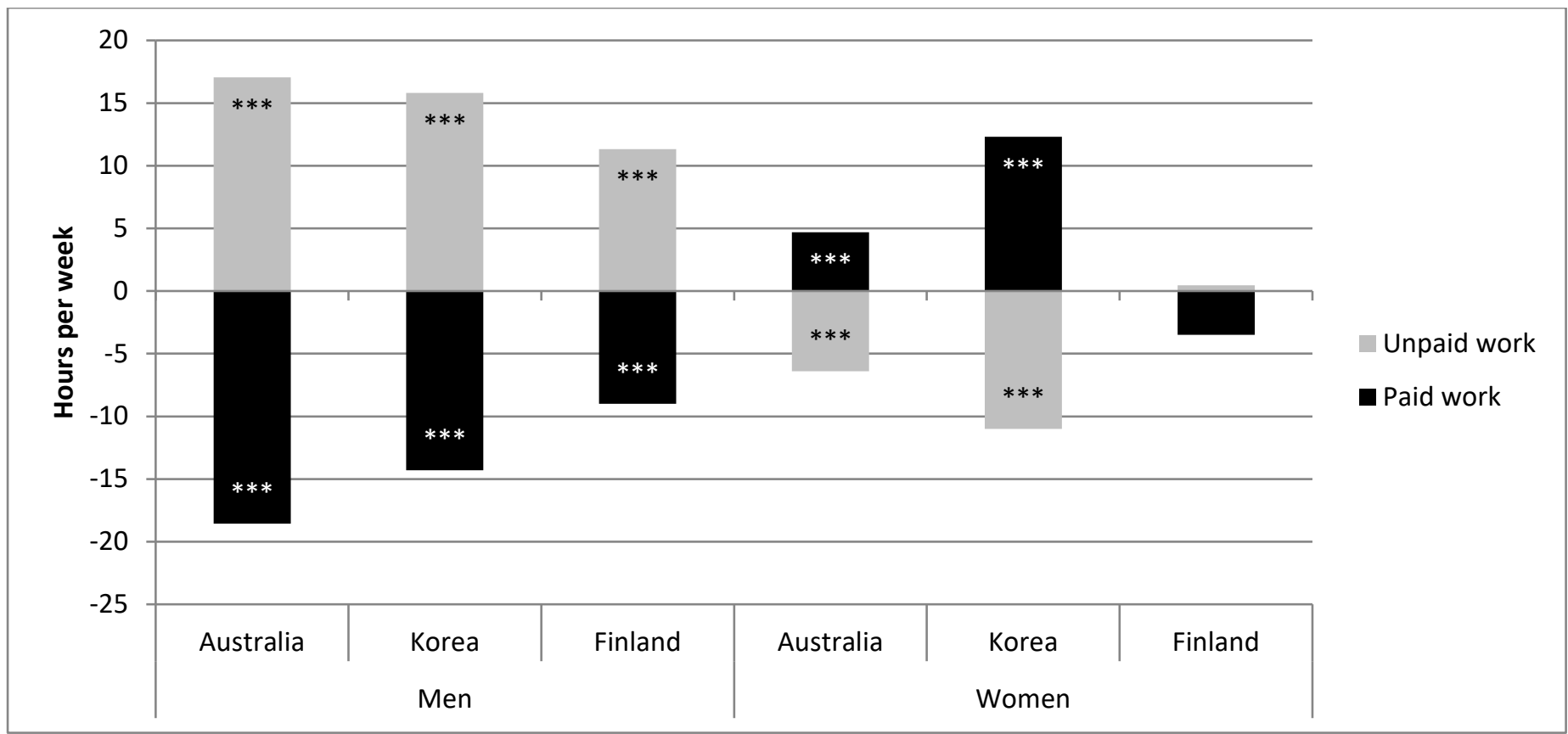

Note: The extent that the bar is above the zero line signifies that more work is done in symmetrical households compared to nonsymmetrical households, and the extent to which the bar is below the zero line signifies that less work is done in symmetrical households compared to non-symmetrical households.

*** signifies that differences between symmetrical and non-symmetrical households were significantly different at $\mathrm{p}<0.001$

Results indicate that it is men's time, rather than women's, that differs most by a/symmetry. Australian, Korean, and Finnish men all averaged significantly less market work and more nonmarket work in symmetrical than in non-symmetrical households. The amounts differed by country. Australian men in symmetrical households did 18.6 hours a week less market work and 17 hours a week more nonmarket work, whereas, Finnish men did 9 fewer hours market work and 11.3 hours more nonmarket work. Korean men in symmetrical households did 14 fewer hours of market work and 15.8 more hours of nonmarket work than men in non-symmetrical households. It is worth noting that even in symmetrical households Korean men average comparatively long employment hours (36.3 weekly hours, compared to 27.3 for Australian men and 22.1 for Finnish men) and these differences were statistically significant.

In Australia and Korea, women in symmetrical households spent significantly more time in market work and less time in nonmarket work than those in non-symmetrical households, but the quantum of difference was much smaller than for men. For Australia the difference by a/symmetry was 4.7 hours market work, and 6.4 hours nonmarket work. In Korea, the difference was more substantial at 12.3 hours more market work, and 11 hours less nonmarket work. For Finnish women, there was no statistical difference between symmetrical and non-symmetrical households in either market or nonmarket work.

We now turn to logistic regression analysis to test whether, within each country, gender a/symmetry is associated with higher odds of time stress, and whether associations differ by gender.

\section{Multivariate analyses}

We modelled the association between gender, work a/symmetry and time stress separately by country. As the interaction gender by a/symmetry was included in the model, the main effect for a/symmetry was for men, and the main effect for women was for those in asymmetrical households. The interaction term captured the effect for women in symmetrical households. 
Table 4 shows that in Australia, men from symmetrical households reported 23 percent [100(0.77-1)] lower odds of being time stressed than men from asymmetrical households. In symmetrical households, women reported 57 percent [100(1.57-1)] higher odds of time stress than men. Supplementary analyses directly comparing Australian women in symmetrical and non-symmetrical households with each other found there no significant difference in their odds of reporting time stress. Taken together this means that in Australia, men in symmetrical households were less time stressed than those asymmetrical households, but women were equally time stressed in both household types.

We performed sensitivity analyses to investigate whether the definition of time stress affected the results for Australia. Using a more restricted definition of time stress ("always" rushed or pressed for time rather than "always or often" rushed or pressed for time) we found similar results as above, with one exception. The direction of association remained the same, but men's odds of reporting time stress did not differ statistically by a/symmetry ( $>>0.05)$. The result for women held, with those in symmetrical households reporting 64 percent [100(1.64-1)] greater odds of time stress than their male counterparts $(\mathrm{p}<0.05)$.

Table 4: Odds Ratios for logistic regression models predicting time stress

\begin{tabular}{|c|c|c|c|}
\hline & Australia & Korea & Finland \\
\hline Female & $\begin{array}{c}0.87 \\
(0.10)\end{array}$ & $\begin{array}{l}0.74^{* * *} \\
(0.06)\end{array}$ & $\begin{array}{c}1.00 \\
(1.20)\end{array}$ \\
\hline Symmetric households & $\begin{array}{l}0.77^{*} \\
(0.09)\end{array}$ & $\begin{array}{c}1.25 \\
(0.17)\end{array}$ & $\begin{array}{c}0.86 \\
(0.14)\end{array}$ \\
\hline Female by symmetric households & $\begin{array}{l}1.57^{* *} \\
(0.24)\end{array}$ & $\begin{array}{c}1.45^{*} \\
(0.25)\end{array}$ & $\begin{array}{c}1.17 \\
(0.29)\end{array}$ \\
\hline Total household work (hours per week) & $\begin{array}{l}1.06^{* * *} \\
(0.01)\end{array}$ & $\begin{array}{l}1.07^{* * *} \\
(0.01)\end{array}$ & $\begin{array}{l}1.04^{* * *} \\
(0.01)\end{array}$ \\
\hline Youngest child is aged $0-4$ & $\begin{array}{l}1.70^{* *} \\
(0.29)\end{array}$ & $\begin{array}{l}1.41^{* *} \\
(0.18)\end{array}$ & $\begin{array}{c}1.71^{*} \\
(0.44)\end{array}$ \\
\hline Youngest child is aged 5-9 & $\begin{array}{l}1.76^{* *} \\
(0.35)\end{array}$ & $\begin{array}{c}0.94^{*} \\
(0.15)\end{array}$ & $\begin{array}{c}2.00 * \\
(0.58)\end{array}$ \\
\hline Youngest child is aged $10-14$ & $\begin{array}{c}1.31 \\
(0.25)\end{array}$ & $\begin{array}{c}1.15 \\
(0.13)\end{array}$ & $\begin{array}{c}1.08 \\
(0.34)\end{array}$ \\
\hline Female by youngest aged $0-4$ & $\begin{array}{c}1.26 \\
(0.26)\end{array}$ & $\begin{array}{c}0.76 \\
(0.11)\end{array}$ & $\begin{array}{c}0.57 \\
(0.20)\end{array}$ \\
\hline Female by youngest aged 5-9 & $\begin{array}{c}1.49 \\
(0.38)\end{array}$ & $\begin{array}{c}0.94 \\
(0.15)\end{array}$ & $\begin{array}{c}0.58 \\
(0.24)\end{array}$ \\
\hline Female by youngest aged 10-14 & $\begin{array}{c}1.05 \\
(0.27)\end{array}$ & $\begin{array}{c}1.09 \\
(0.15)\end{array}$ & $\begin{array}{c}0.92 \\
(0.36)\end{array}$ \\
\hline Age & $\begin{array}{l}0.98^{* * *} \\
(0.00)\end{array}$ & $\begin{array}{l}0.98^{* * *} \\
(0.00)\end{array}$ & $\begin{array}{c}0.99 \\
(0.01)\end{array}$ \\
\hline Both partners have college degree & $\begin{array}{c}1.28 * \\
(0.14)\end{array}$ & $\begin{array}{l}1.50^{* * * *} \\
(0.12)\end{array}$ & $\begin{array}{c}1.15 \\
(0.22)\end{array}$ \\
\hline Number of adults in household is $3+$ & $\begin{array}{l}1.38^{* *} \\
(0.14)\end{array}$ & $\begin{array}{c}1.10 \\
(0.08)\end{array}$ & $\begin{array}{c}1.06 \\
(0.19)\end{array}$ \\
\hline
\end{tabular}

Reference category: male, asymmetric households, no children, partners do not both have a college degree, 2 adults in household. Standard errors in parentheses.

${ }^{*} p<0.05,{ }^{* *} p<0.01,{ }^{* * *} p<0.001$

In Korea, gender symmetry was positively associated with time stress in for women. Those in symmetrical households reported 45 percent [100(1.45-1)] higher odds of time stress than their male counterparts. However, in non-symmetrical households, women had significantly lower time stress than men. These 
women reported 26 percent [100(0.74-1)]) lower odds of time stress than their male counterparts. This is not surprising given the large difference in market work hours of men (51) and women (22) in asymmetrical households. Supplementary analyses showed that if the coding for gender was reversed such that women were the referent group, Korean women in symmetrical households reported 81 percent [100(1.81-1)] higher odds of time stress $(\mathrm{p}<0.001)$ than Korean women in asymmetrical households.

It should be recalled that less than 6 percent of Korean households are gender-symmetrical, and that women's time allocation difference by gender a/symmetry is the widest of the three countries. Korean women who share market and nonmarket work equally with their spouse are very unusual, and do much more paid work than their compatriots in non-symmetrical households. Korean men report no difference in time stress by a/symmetry. Again, it should be noted that average market work hours for Korean men are high, even in gender-symmetrical households.

Finally, the logistic regressions revealed no significant associations between a/symmetry and time stress in Finland for either men or women. This may be due to the relatively small differences in gender time allocation between symmetrical and non-symmetrical households, or the low average total household work hours in Finland reducing time stress for all.

\section{Discussion and Conclusion}

Despite predictions of role convergence over the last half-century, "symmetrical families" in which men and women share equally in market and in nonmarket work have not become the statistical norm (Young and Wilmott 1973, Bergmann 1986, Fisher et al. 2007, Bianchi et al. 2000, Sullivan 2006). This paper explored the possibility that a contributing factor could be that gender time symmetry is accompanied by higher time stress, making it "just too hard" for most families to achieve. We conducted a three-country study, on the assumption that national social and economic policies and practices could exacerbate or ameliorate stress costs related to gender time symmetry. Our results suggest that this was the case.

The three countries chosen had contrasting institutional features and social policy frameworks (summarized in Table 1). Finland has the most extensive work-family supports and is the most progressive in promoting gender equality (Gornick and Meyers 2003, Gershuny and Sullivan 2003). Australia is a liberal country in which work-family policy measures are thin, male working hours are long and there is a high incidence of part time work for women (Craig and Mullan 2010). Korea, which the fits the welfare regime description liberal-familialist (Kwon 2005, Lee 2005, Ochiai 2009), has even fewer institutional supports for workfamily reconciliation and very long male working hours. Against this backdrop, we found marked crossnational contrast in average couple work total hours, the incidence of time symmetry, and its association with time stress. These differences confirm that context does matter and gives pointers to specific policy direction. In particular, our findings suggest that shorter average national male employment hours may be prerequisite to stress-free gender time equality.

One indication is that, in Finland, gender symmetry did not involve higher subjective time stress for either gender. This may be because, as is to be expected for a social democratic country that promotes gender equality, symmetry was much more common there than in the other two countries and time variation between the two household types was not extreme. Symmetry was not universal, but, on average, Finnish men would need to only slightly alter their work composition to achieve it, and Finnish women would not need to change at all. They already average an almost equal balance between market and nonmarket work. But importantly, Finnish total household workloads were substantially shorter than in the other countries, and this was largely due to male market work hours being particularly low, even in non-symmetrical households. The implication of our results is that lower country average working hours create flexibility not only for men and women to share market and nonmarket work equally, but to do so without added time stress. 
This possibility is further supported by our findings for Korea, where average male work hours are very high, and symmetry is very unusual. In non-symmetrical households, women devoted a high proportion of their time to nonmarket work and had significantly lower time stress than men. When symmetry did exist, it was accompanied by much more time stress for women, and no reduction in time stress for men. Of our three countries, Korean patterns correspond most closely to the idea that role convergence brings more gender symmetry in the division of labor at the cost of higher time stress. However, it is pertinent that symmetry was not associated with a higher overall (market and nonmarket) household workload within that country, but rather with an altered household work composition, such that a larger proportion of household work time was devoted to paid employment. In Korean symmetrical households, women were going against the norm in doing much more market work than the country average, and their partners also did a sizable amount of market work. Nonmarket work for both genders was low in world terms. The results suggest that where average paid work hours are highest and allow little time for maintaining the domestic sphere there are stress costs associated with symmetry. They also suggest there is a stress cost in exercising individual agency and pursuing a gender equal work division in a country where it is unusual and not well-supported by social and workplace policies.

Patterns in Australia also suggest that work composition matters to time stress, but gender outcomes differed. As in Finland, but in contrast to Korea, symmetry in Australia involved a higher proportion of total household work being unpaid, rather than paid. This outcome was largely driven by men. The Australian norm of female part time work hours meant symmetrical work arrangements involved men deviating markedly from average male employment patterns. Thus, for men, symmetry meant a big time allocation shift from the norm, with substantially more nonmarket work and less market work. This shift was associated with significantly less male time stress. As within the other two countries, we did not find that symmetrical households did more or less work in total, which implies that the stress benefit from symmetry came from the changed composition of men's work. Notably, in symmetrical Australian households women were more stressed than men, so the benefit their husbands enjoyed did not extend to them. This is likely because the women were themselves substituting market for nonmarket work. However, intriguingly, our supplementary analyses showed no stress difference between women in symmetrical and non-symmetrical households. This suggests that, like Korean women, Australian men experience lower time stress when they have a work composition which includes relatively more nonmarket work, but Australian women do not. This result may arise from gender differences in what type of nonmarket work is performed and to what standard. This possibility could be pursued in future research. It could also be because, on average, in Australian non-symmetrical households, men's work hours are long, which has been found to be positively associated not only with their own, but also with their wife's, subjective time stress (Craig and Brown 2016).

This analysis is subject to a number of limitations. We cannot identify why couples adopt gender symmetry so, for example, do not know if it is a result of deliberate decision or couple negotiation, or due to ill health or job loss, perhaps in economic downturn (Bell and Blanchflower 2010, Karamessini and Rubery 2013). There may be selection bias, particularly in Korea and Australia. Our results are associations only, and with cross-sectional data cannot identify causal direction between time use and time pressure. Also, we cannot directly link the results to specific policies.

Nonetheless, there are implications from the cross-national patterns we identify including that achieving gender time equality without high and gendered stress costs is facilitated if average male paid work hours are not overly long. Shorter work-weeks are not a current policy focus in liberal or liberal-familialist countries, despite some experiencing under- or unemployment and consequent social inequality. Rather, "family friendly" measures including flexible hours and working from home, which shift work time or location, are widely suggested as solutions to contemporary time pressures (Powell and Craig 2015, Halpern 2005). However, to date such measures are much more likely to be taken up by women than by men, adding to gender disparity in career progression and wealth accumulation (Lewis 2001, Whittock et al. 2002, Chalmers and Hill 2007). Goldin argues that the last remaining chapter in the "grand gender convergence" is allowing employees "temporal flexibility", but also points out that long full time work hours are a major 
cause of the current inequality (Goldin 2014). Many caution that without employment time reduction, rescheduling work to times outside the standard working week potentially facilitates work intensification, work extension, work-family conflict and higher time stress (Wajcman 2016, Kelliher and Anderson 2010, Shockley and Allen 2007, Slaughter 2012). On balance, it seems that shifting work time is likely to be less useful in lowering family time stress than reducing male employment hours. This might be thought likely to lower national economic productivity, but social democratic countries perform highly on such measures (OECD 2015), suggesting that a better time balance between work and family and a higher average incidence of symmetry is not inimical to economic wellbeing. Moreover, a low average incidence of symmetry may be inimical to social wellbeing. The results of this study suggest that in a policy framework in which it is rare, gendered time equality comes at the cost of higher time stress.

\section{References}

Anxo, Dominique, Colette Fagan, Inmaculada Cebrian, and Moreno Gloria. 2007. "Patterns of labour market integration in Europe--a life course perspective on time policies " Socio-Economic Review no. 5 (2):233-260.

Baxter, Janeen, Belinda Hewitt, and Michele Haynes. 2008. "Life Course Transitions and Housework: Marriage, Parenthood, and Time on Housework." Journal of Marriage and Family no. 70 (2):259272.

Beaujot, R., and R. Andersen. 2007. "Time-crunch: Impact of time spent in paid and unpaid work, and its divisions in families." Canadian Journal of Sociology no. 32:295-315. doi: 10.2307/20460645.

Bell, David, and David Blanchflower. 2010. "UK unemployment in the great recession." National Institute Economic Review, no. 214 (1):R3-R45. doi: 10.1177/0027950110389755.

Bergmann, Barbara. 1986. The Economic Emergence of Women. New York: Basic Books, Inc.

Bianchi, Suzanne, and Melissa Milkie. 2010. "Work and Family Research in the First Decade of the 21st Century." Journal of Marriage and Family no. 72 (3 ):705-725. doi: 10.1111/j.17413737.2010.00726.x.

Bianchi, Suzanne, Melissa Milkie, Liana Sayer, and John Robinson. 2000. "Is anyone doing the housework? Trends in the gender division of household labor." Social Forces no. 79 (1):191-228. doi: 10.1093/sf/79.1.191.

Chalmers, Jenny, and Trish Hill. 2007. "Marginalising Women in the Labour Market: 'Wage Scarring' Effects of Part-time Work." Australian Bulletin of Labour no. 33 (2):180-201.

Connell, Robert 2003. The role of men and boys in achieving gender equality. In UN Expert Group Meeting on The role of men and boys in achieving gender equality. Brasilia, Brazil.

Craig, Lyn, and Janeen Baxter. 2016. "Domestic outsourcing, housework shares and subjective time pressure: gender differences in the correlates of hiring help." Social Indicators Research no. 125 (1):271-288. doi: 10.1007/s11205-014-083-1.

Craig, Lyn, and Judith Brown. 2016. "Feeling rushed: gendered time quality, work hours, work schedules and spousal crossover." Journal of Marriage and Family. doi: online first 10.1111/jomf.12320.

Craig, Lyn, and Killian Mullan. 2009. "The Policeman and the Part-time Sales Assistant: Household labour supply, family time and subjective time pressure in Australia 1997-2006." Journal of Comparative Family Studies no. 40 (4):545-560.

Craig, Lyn, and Killian Mullan. 2010. "Parenthood, gender and work-family time in USA, Australia, Italy, France and Denmark " Journal of Marriage and Family no. 72 (5):1344-1361.

Craig, Lyn, Killian Mullan, and Megan Blaxland. 2010. "Parenthood, Policy and Work-Family Time in Australia 1992-2006." Work, Employment and Society no. 24 (1):1-19. doi: 10.1177/0950017012437006. 
Crompton, Rosemary. 2006. Employment and the Family. The Reconfiguration of Work and Family Life in Contemporary Societies. Cambridge: Cambridge University Press.

de Laat, Joost, and Almudena Sevilla Sanz. 2004. Working Women, Men’s Home Time and Lowest-Low Fertility in Europe. Department of Economics, Brown University.

Deding, M., and M. Lausten. 2011. "Gendered time-crunch and work factors in Denmark." Social Indicators Research no. 101:249-253. doi: 10.1007/s11205-010-9643-2.

Edwards, Paul, and Judy Wajcman. 2005. The Politics of Working Life: Oxford University Press.

Esping-Andersen, Gøsta. 2009. The Incomplete Revolution: Adapting to Women’s New Roles. Cambridge: Polity Press.

Fisher, Kimberly, Muriel Egerton, Jonathan Gershuny, and John Robinson. 2007. "Gender Convergence in the American Heritage Time Use Study (AHTUS)." Social Indicators Research no. 82 (1):1-33. doi: 10.1007/s11205-006-9017-y.

Gershuny, Jonathan. 2011. "Increasing Paid Work Time? A New Puzzle for Multinational Time-diary Research." Social Indicators Research no. 101:207-213.

Gershuny, Jonathan, and Oriel Sullivan. 2003. "Time Use, Gender and Public Policy Regimes." Social Politics no. 10 (2):205-228.

Goldin, Claudia. 2014. "A Grand Gender Convergence: Its Last Chapter." The American Economic Review no. 104 (4):1091-1119. doi: http://dx.doi.org/10.1257/aer.104.4.1091.

Gornick, Janet, and Marcia Meyers. 2003. Families that Work: Policies for Reconciling Parenthood and Employment. New York: Russell Sage.

Halpern, Diane. 2005. "How time-flexible work policies can reduce stress, improve health, and save money." Stress and Health no. 21 (3):157-168.

Hamermesh, Daniel, and Jungmin Lee. 2007. "Stressed Out on Four Continents: Time Crunch or Yuppie Kvetch?" The Review of Economics and Statistics no. 89 (2):374-383.

Hartmann, Heidi. 1981. "The Unhappy Marriage of Marxism and Feminism: Towards a More Progressive Union." In Women and Revolution: A Discussion of the Unhappy Marriage of Marxism and Feminism, edited by Lydia Sargent.

Hausmann, Ricardo, Laura D. Tyson, and Saadia Zahidi. 2009. The Global Gender Gap Report. In Insight Report. Geneva, Switzerland: World Economic Forum.

Hill, Jeffrey , Vjollca K. Märtinson, Maria Ferris, and Robin Zenger Baker. 2004. "Beyond the Mommy Track: The Influence of New-Concept Part-Time Work for Professional Women on Work and Family." Journal of Family and Economic Issues no. 25 (1):121 - 136.

Hook, Jennifer. 2006. "Care in context: Men's unpaid work in 20 countries, 1965-2003." American Sociological Review no. 71 (4):639-660.

Hook, Jennifer. 2010. "Gender Inequality in the Welfare State: Sex Segregation in Housework, 1965-2003." American Journal of Sociology no. 115 (5):1480-1523.

HREOC. 2007. It's About Time: Women, Men, Work and Family. Sydney: Human Rights and Equal Opportunity Commission.

Jacobs, Jerry, and Kathleen Gerson. 2004. The Time Divide: Work, Family, and Gender Inequality. Cambridge, Massachusetts: Harvard University Press.

Kan, Man Yee, Oriel Sullivan, and Jonathan Gershuny. 2011. "Gender Convergence in Domestic Work: Discerning the Effects of Interactional and Institutional Barriers from Large-scale Data." Sociology no. 45:234-251. 
Karamessini, Maria, and Jill Rubery, eds. 2013. Women and austerity: The economic crisis and the future for gender equality. USA and Canada: Routledge.

Kelliher, Clare, and Deirdre Anderson. 2010. "Doing more with less? Flexible working practices and the intensification of work." Human Relations no. 63 (1):83-106.

Kleiner, Sibyl. 2014. "Subjective Time Pressure: General or Domain Specific?" Social Science Research no. 47 (1):108-120.

Kwon, Huck-Ju 2005. Transforming the developmental welfare states in East Asia. Edited by Huck-Ju Kwon. New York: Palgrave Macmillan.

Lee, Eliza. 2005. "The politics of the welfare developmentalism in Hong Kong." In Transforming the developmental welfare states in East Asia, edited by Huck-Ju Kwon. New York: Palgrave Macmillan.

Lewis, Jane. 2009. Work-Family Balance, Gender and Policy. Cheltenham, UK, Northhampton, MA, USA: Edward Elgar.

Lewis, Suzan 2001. "Restructuring workplace cultures: the ultimate work-family challenge?" Women in Management Review no. 16 (1):21 - 29.

MacDonald , M., S. Phipps, and L. Lethbridge. 2005. "Taking Its Toll: The Influence of Paid and Unpaid Work on Women's Well-Being." Feminist Economics no. 11:63-94. doi: 10.1080/1354570042000332597.

Mattingly, Marybeth, and Liana Sayer. 2006. "Under pressure: Gender differences in the relationship between free time and feeling rushed." Journal of Marriage and the Family no. 68 (1):205-221.

McDonald, Peter. 2006. "Low Fertility and the State: The Efficacy of Policy." Population and Development Review no. 32 (3):485-510.

Mullan, Killian, and Lyn Craig. 2009. "Harmonising extended measures of parental childcare in the timediaries of four countries: proximity versus responsibility." electronic International Journal of Time Use Research no. 6 (1):48-72.

Nedelsky, Jennifer 2016. "(Part)-Time for All: Norms to Transform The Crisis of Work and Care."

O'Connor, Julia, Ann Orloff, and Sheila Shaver. 1999. States, Markets, Families. Cambridge: Cambridge University Press.

Ochiai, Emiko 2009. "Care diamonds and welfare regimes in East and South-East Asian Societies: Bridging Family and Welfare Sociology." International Journal of Japanese Sociology no. 18 60-78.

OECD. 2016. Level of GDP per capita and productivity. Organisation for Economic Co-operation and Development 2015 [cited 6/8/16 2016]. Available from http://stats.oecd.org/Index.aspx?DataSetCode=PDB_LV.

Orloff, Ann. 2009. "Gendering the Comparative Analysis of Welfare States: An Unfinished Agenda." Sociological Theory no. 27 (3):317-343.

Plibersek, Tanya. 2008. Women and Men: A New Conversation about Equality. Sydney: The Sydney Institute.

Pocock, Barbara. 2003. The Work/Life Collision. Sydney: Federation Press.

Powell, Abigail, and Lyn Craig. 2015. "Gender differences in working at home and time use patterns: evidence from Australia." Work, Employment and Society no. 29 (4):571-589. doi: $10.1177 / 0950017014568140$.

Presser, Harriet. 2003. Working in a 24/7 Economy: Challenges for American Families. New York: Russell Sage Foundation. 
Robinson, John P., and Geoffrey Godbey. 1997. Time For Life. The Surprising Ways Americans Use Their Time. University Park: Pennsylvania State University Press.

Sayer, Liana. 2016. "Trends in Women’s and Men’s Time Use, 1965-2012: Back to the Future?" Gender and Couple Relationships no. Volume 6 of the series National Symposium on Family Issues 43-77.

Sayer, Liana, and Janet Gornick. 2012. "Cross-national Variation in the Influence of Employment Hours on Child Care Time." European Sociological Review no. 28 (4):421-442. doi: 10.1093/esr/jcr008

Schulte, Brigid. 2014. Overwhelmed: How to Work, Love and Play when No One has the Time. . USA: Sarah Chriton Books.

Shockley, Kristen, and Tammy Allen. 2007. "When does flexibility help: Another look at the availability of flexible work arrangements and work-family conflict." Journal of Vocational Behavior no. 71 (3):479-493.

Slaughter, Anne Marie. Why Women Still Can't Have It All 2012 [cited 3/10/16. Available from http://www.theatlantic.com/magazine/archive/2012/07/why-women-still-cant-have-it-all/309020/.

Strazdins, Lyndall, Amy Griffin, Dorothy Broom, Cathy Banwell, Rosemary Korda, Jane Dixon, Francesco Paolucci, and John Glover. 2011. "Time scarcity: another health inequality?" Environment and Planning no. 43:545-559.

Sullivan, Oriel. 2006. Changing Gender Relations, Changing Families: Tracing the Pace of Change over Time, Gender Lens Series. New York: Rowman \& Littlefield.

Sullivan, Oriel. 2011. "An End to Gender Display through the Performance of Housework? A Review and Reassessment of the Quantitative Literature Using Insights from the Qualitative Literature." Journal of Family Theory \& Review no. 3 (1):1-13.

Wajcman, Judy. 2016. Pressed for Time: The Acceleration of Life in Digital Capitalism, . Chicago: The University of Chicago Press.

Whittock, Margaret, Christine Edwards, Susan McLaren, and Olive Robinson. 2002. "The tender trap: gender, part-time nursing and the effects of 'family-friendly' policies on career advancement." Sociology of Health and Illness no. 24 (3):305-326.

Young, Michael, and Peter Wilmott. 1973. The Symmetrical Family: A Study of Work and Leisure in the London Region. London: Routledge. 
Table A1 Primary/main activity codes for Italy, Australia and Korea

\begin{tabular}{|l|l|l|l|}
\hline & Australia & Korea & Finland \\
\hline Market work & $200-299$ & $211-299,2601,2602,821,822$ & $111-112,129,910$ \\
\hline Childcare & $500-599$ & $511-523,851,5121-5292$ & $381-389,938$ \\
\hline Domestic /purchasing & $\begin{array}{l}400-499 \text { and } \\
600-699\end{array}$ & $\begin{array}{l}\text { 240, 411-499, 841, 3301, 4411-4532, } \\
5301-5509,6101-6109,7801,7802\end{array}$ & $300-371$ \\
\hline
\end{tabular}

Table A2: Regression coefficients for time spent in market and nonmarket work by country

\begin{tabular}{|c|c|c|c|c|c|c|}
\hline \multirow{3}{*}{$\begin{array}{l}\text { Number of diaries } \\
\text { Household market work }\end{array}$} & \multicolumn{2}{|c|}{ Australia } & \multicolumn{2}{|c|}{ Korea } & \multicolumn{2}{|c|}{ Finland } \\
\hline & \multicolumn{2}{|c|}{2873} & \multicolumn{2}{|c|}{8748} & \multicolumn{2}{|c|}{1543} \\
\hline & \multirow{2}{*}{\multicolumn{2}{|c|}{$\begin{array}{c}-14.12 * * * \\
(2.94)\end{array}$}} & & & & \\
\hline & & & \multicolumn{2}{|c|}{$\begin{array}{l}-2.75 \\
(3.32)\end{array}$} & \multicolumn{2}{|c|}{$\begin{array}{c}-13.58 * * * \\
(3.58)\end{array}$} \\
\hline Weekday & \multicolumn{2}{|c|}{$\begin{array}{l}57.34^{* * *} \\
(2.04)\end{array}$} & \multicolumn{2}{|c|}{$47.75^{* * *}$} & \multicolumn{2}{|c|}{$\begin{array}{l}55.04^{* * *} \\
(2.22)\end{array}$} \\
\hline Constant & \multicolumn{2}{|c|}{$\begin{array}{l}24.81^{* * * *} \\
(1.50)\end{array}$} & \multicolumn{2}{|c|}{$\begin{array}{l}38.87 * * * \\
(0.93)\end{array}$} & \multicolumn{2}{|c|}{$\begin{array}{l}1 / .53 \\
(1.77)\end{array}$} \\
\hline \multicolumn{7}{|l|}{ Household } \\
\hline Symmetrical household & \multicolumn{2}{|c|}{$\begin{array}{l}11.08^{* * *} \\
(2.06)\end{array}$} & \multicolumn{2}{|c|}{$\begin{array}{l}5.09 * \\
(2.24)\end{array}$} & \multicolumn{2}{|c|}{$\begin{array}{l}12.63 * * * \\
(2.38)\end{array}$} \\
\hline Weekday & \multicolumn{2}{|c|}{$\begin{array}{c}-13.41 * * * \\
(1.57)\end{array}$} & \multicolumn{2}{|c|}{$\begin{array}{l}-6.20 * * * \\
(0.72)\end{array}$} & \multicolumn{2}{|c|}{$-5.52 * * *$} \\
\hline Constant & \multicolumn{2}{|c|}{$\begin{array}{l}68.26^{* * * *} \\
(1.31)\end{array}$} & \multicolumn{2}{|c|}{$\begin{array}{l}46.00^{* * * *} \\
(0.56)\end{array}$} & \multicolumn{2}{|c|}{$\begin{array}{l}48.88^{* * * *} \\
(1.33)\end{array}$} \\
\hline & \multicolumn{5}{|c|}{ Individual market work } & Women \\
\hline Symmetrical household & $\begin{array}{c}-18.56^{* * *} \\
(1.63)\end{array}$ & $\begin{array}{l}4.70 * * \\
(1.49)\end{array}$ & $\begin{array}{c}-14.30 * * * \\
(1.56)\end{array}$ & $\begin{array}{c}12.30^{* * * *} \\
(1.73)\end{array}$ & $\begin{array}{c}-8.99 * * * \\
(2.00)\end{array}$ & $\begin{array}{l}-3.50 \\
(1.89)\end{array}$ \\
\hline Weekday & $\begin{array}{l}34.97 * * * \\
(1.36)\end{array}$ & $\begin{array}{l}21.21^{* * *} \\
(1.16)\end{array}$ & $\begin{array}{l}32.25^{* * *} \\
(0.80)\end{array}$ & $\begin{array}{l}15.59 * * * \\
(0.77)\end{array}$ & $\begin{array}{l}29.75^{* * *} \\
(1.47)\end{array}$ & $\begin{array}{l}24.95^{* * * *} \\
(1.28)\end{array}$ \\
\hline Constant & $\begin{array}{l}20.84^{* * * *} \\
(1.08)\end{array}$ & $\begin{array}{l}3.83^{* * *} \\
(0.76)\end{array}$ & $\begin{array}{l}27.57 * * * \\
(0.67)\end{array}$ & $\begin{array}{l}11.06^{* * * *} \\
(0.50)\end{array}$ & $\begin{array}{l}9.81^{* * *} \\
(1.20)\end{array}$ & $\begin{array}{l}7.11^{* * *} \\
(0.97)\end{array}$ \\
\hline \multicolumn{7}{|l|}{ Individual } \\
\hline Symmetrical household & $\begin{array}{l}17.03^{* * *} \\
(1.05)\end{array}$ & $\begin{array}{l}-6.40 * * * \\
(1.18)\end{array}$ & $\begin{array}{c}15.81 * * * \\
(0.98)\end{array}$ & $\begin{array}{c}-11.00 * * * \\
(1.19)\end{array}$ & $\begin{array}{c}11.33^{* * * *} \\
(1.21)\end{array}$ & $\begin{array}{c}0.47 \\
(1.34)\end{array}$ \\
\hline Weekday & $\begin{array}{l}-9.11^{* * *} \\
(0.84)\end{array}$ & $\begin{array}{l}-3.18^{* *} \\
(1.08)\end{array}$ & $\begin{array}{l}-4.95 * * * \\
(0.29)\end{array}$ & $\begin{array}{l}-1.64 * * \\
(0.57)\end{array}$ & $\begin{array}{c}-3.14 * * * \\
(0.80)\end{array}$ & $\begin{array}{l}-2.32^{* *} \\
(0.81)\end{array}$ \\
\hline Constant & $\begin{array}{l}23.28 * * * \\
(0.72)\end{array}$ & $\begin{array}{l}45.04^{* * *} \\
(0.85)\end{array}$ & $\begin{array}{l}8.91^{* * *} \\
(0.25)\end{array}$ & $\begin{array}{c}37.25^{* * *} \\
(0.42)\end{array}$ & $\begin{array}{c}18.74 * * * \\
(0.74)\end{array}$ & $\begin{array}{l}30.58 * * * \\
(0.87)\end{array}$ \\
\hline
\end{tabular}

$* p<.05, * * p<.01, * * * p<.001$

Note: Standard errors in parentheses.

${ }^{1}$ All descriptive statistics and models were weighted to account for unequal distribution of days of the week, as appropriate. Standard errors were estimated using Taylor linearization to take into account that the matched husbands and wives were clustered within households and diary days within individuals. Analyses were performed using Stata version 14.0.

${ }^{2}$ Unless otherwise noted, all comparisons deemed significant were significant at $\mathrm{p}<0.001$.

${ }^{3}$ Significant at $\mathrm{p}<.05$ 


\section{University Library}

\section{- M I N E R VA}

\section{A gateway to Melbourne's research publications}

Minerva Access is the Institutional Repository of The University of Melbourne

Author/s:

Craig, L;Brown, JE;Strazdins, L;Jun, J

Title:

Is It Just Too Hard? Gender Time Symmetry in Market and Nonmarket Work and Subjective Time Pressure in Australia, Finland, and Korea

Date:

2017

\section{Citation:}

Craig, L., Brown, J. E., Strazdins, L. \& Jun, J. (2017). Is It Just Too Hard? Gender Time Symmetry in Market and Nonmarket Work and Subjective Time Pressure in Australia, Finland, and Korea. Connelly, R (Ed.). Kongar, E (Ed.). Gender and Time Use in a Global Context The Economics of Employment and Unpaid Labor, (1), pp.465-494. Palgrave Macmillan.

Persistent Link:

http://hdl.handle.net/11343/251911 